\title{
Conducting personnel audit in compliance with international standards
}

\author{
Guzaliya $\mathrm{Klychova}^{1}$, Jamila Leontieva ${ }^{2}$, Alsou Zakirova ${ }^{1 *}$, Evgenia Zaugarova ${ }^{2}$, Shaukat \\ Khusainov $^{3}$, and Ildus Gimadiev ${ }^{1}$ \\ ${ }^{1}$ Kazan State Agrarian University, Department of Accounting and Audit, 420015 Kazan, Russia \\ ${ }^{2}$ Saint-Petersburg State Economic University, Department of Accounting and Analysis, 191023 St. \\ Petersburg, Russia \\ ${ }^{3}$ Russian State Agrarian University - Moscow Timiryazev Agricultural Academy, 127550, Moscow, \\ Russia
}

\begin{abstract}
The present research studies basic principles of personnel audit, considers new requirements for auditing due to the entry into force of international standards, develops working documents for the auditor that allow increasing the efficiency of personnel audit and coordinating audit procedures with the work of the personnel at the audited company, applying general scientific methods, such as systematic approach, comparison, economic-statistical method, method of systematization and generalization of data. The article describes the main stages of the personnel audit, reveals mechanism for organizing, planning, conducting, and issuing the results of the personnel audit, provides specific material, which helps to develop an idea on the personnel audit fulfillment at the level of an individual economic entity. The research offers methodological toolkit of personnel audit, which makes it possible to assess the state of the personnel management system, the interests and values of an employee, his attitude to the existing problems and their comprehension.
\end{abstract}

\section{Introduction}

The growth of profits and increase in the efficiency of activities is an important task of the current development of organizations belonging to the agrarian sector of the economy. In this respect, issues related to the efficient application of human resources, which are an important factor of production, are of a particular relevance.

For a successful fulfillment of its activity, any organization shall analyze the labor indicators, allowing the most accurate assessment of the technical and economic potential; identifying the reserves of effective use of staff; improving working and payment conditions; seeking ways of settling social and labor relations in the workforce, etc [1-3].

For a long time, the management of any enterprise, as well as the audit of different areas of its activity has mainly been focused on achieving effective, rational and economical use of material and financial resources, while the labor resources have not been considered as a tool for promotion of an effective functioning of an enterprise $[4,5]$.

*Corresponding author: zakirovaar@mail.ru 
Currently, the main problems of labor relations in organizations include the shortage of qualified specialists with a sufficient work experience, poorly established and unbalanced policy of selection and certification of specialists. In order to assess the staff performance, it is necessary to apply various diagnostic measures, one of which is a personnel audit.

Personnel audit is a set of methods and principles for the implementation of independent verification of the organization personnel in terms of its compliance with the goals and objectives, assessment of achievements in knowledge management, assessment of employees 'personal potential, examination of personnel structures activity, aimed at identifying and eliminating contradictions and inconsistencies in the financial and business activities of the organization.

The purpose of the personnel audit is to diagnose the personnel policy in the audited economic entity, assess its impact on the tactical and strategic management systems of production and socio-economic activity; the development of a set of activities aimed at eliminating of the identified deficiencies [4].

The main lines of the personnel audit:

1. Control of the enterprise personnel policy formation involving the assessment of the current state of the personnel policy, its coordination with the goals of the enterprise and its development strategy $[6,7]$.

2. Control of the staff planning, involving the determination of resources availability, assessment of goals and development prospects of the enterprise, and the future need for staff.

3. Control of the staff application, involving the analysis of the level of staff employment and stable staff composition.

4. Control of the recruitment and selection of personnel, involving the assessment of methods of staff recruitment, sources and ways to cover staffing needs [8].

5. Assessment of staff business qualities, involving the analysis of the applied forms for business valuation and the frequency of its implementation.

6. Control of the staff training process, involving an assessment of trained personnel and the effectiveness of carried out training.

7. Control of the labor relations in the workforce, involving the diagnostics of sociopsychological climate, as well as the assessment of the level of social tension at the enterprise.

\section{Materials and Methods}

During the audit of labor resources, evidence is collected, which is necessary to form an objective conclusion in respect of the audited entity activity [9]. For collecting audit evidence various tools can be applied, including a set of methods, which involve conducting surveillance of key management communications; documentation analysis; expert surveys; social experiments; questioning and interviewing the heads of the departments; group discussion [10-12].

The system of indicators is calculated in the process of labor resources audit. It allows characterizing the effectiveness and efficiency both of the personnel and the organization of labor relations on the whole [13-14]; as well as the effectiveness of motivation and remuneration system; rationality of labor assessment methods; the effectiveness of individual jobs organization; efficiency and rationality of the working time use, etc [15].

Regardless of the methods used, the technology for conducting a personnel audit has a logical sequence of actions and includes the following steps: preparatory, functional, final.

Stage 1 - preparatory. At this stage, in accordance with the International Standard of Audit 210 "Coordination of audit assignment conditions", negotiations regarding the personnel audit are carried out with the customer, risks are assessed, documents are 
prepared for a personnel audit, an agreement is signed between the interested parties, and an audit team is formed.

When negotiating with customers, the head of an audit organization conducting the personnel audit preliminarily assesses the scope and content of work. In particular, the goal of a personnel audit is set; the results of personnel audit and the possibility of their use by the customer; the specifics and scope of the customer organization; the complexity and labor intensity of the personnel audit taking into account the industry and regional characteristics of the customer; socio-economic problems existence in the workforce of the customer; the availability and condition of the internal control system [16], the state of socio-economic reporting [17].

The necessary information allowing the assessment of the possibilities for an order fulfillment and provision of qualified personnel auditors can be obtained during personal conversations with the management and specialists of the contracting authority, as well as inspecting objects, and studying documentation.

The level of audit risk shall be established after the goals and objectives of the personnel audit are defined. It is assumed by the audit organization which conducts a personnel audit through providing a conclusion on the achievement of an appropriate knowledge level and personal potential of employees, the effectiveness of personnel structures, and reliability of socio-economic data reporting, while there may be omissions and errors, which have missed the view of the personnel auditor.

A special role in the process of personnel audit is assigned to planning, upon which depends the rational use of labor resources of the audit team, minimizing the time and cost of personnel audit [18].

The audit plan in accordance with the requirements of ISA 300 "Planning the audit of financial statements" includes the following sections:

1. Understanding of business including a description of the general economic factors and conditions in the industry affecting the business of an audited entity; important characteristics of the subject; financial and business performance results and reporting requirements; general level of competence of management [19].

For example, the subject of discussion and the actions of the auditor may be reflected (Table 1) in a personnel audit, particularly in the description of the audited organization activity understanding [4].

Table 1.The audited organization activity understanding

\begin{tabular}{|c|c|}
\hline Subject of discussion & Auditor's activity \\
\hline \multicolumn{2}{|c|}{ Structure and management system evaluation } \\
\hline $\begin{array}{l}\text { Mission, strategy and goals of the } \\
\text { organisation evaluation }\end{array}$ & $\begin{array}{l}\text { We shall evaluate the availability and mutual } \\
\text { coordination of mission, strategy and current } \\
\text { goals of the organisation }\end{array}$ \\
\hline $\begin{array}{l}\text { Evaluation of managerial decisions } \\
\text { fulfillment by the employees }\end{array}$ & $\begin{array}{l}\text { We shall analyse the contents and quantity of } \\
\text { decisions not being fulfilled, reviewd, requie } \\
\text { additional elaboration }\end{array}$ \\
\hline $\begin{array}{l}\text { Evaluation of organisation structure } \\
\text { compliance with the modern } \\
\text { conditions }\end{array}$ & $\begin{array}{l}\text { We shall determine the availability or absence of } \\
\text { structure governance over the function, } \\
\text { bureaucratization, stagnation and copying of } \\
\text { organization order }\end{array}$ \\
\hline \multicolumn{2}{|l|}{ Evaluation of personnel activity } \\
\hline $\begin{array}{l}\text { Evaluation of professional and } \\
\text { innovative potential of an employee }\end{array}$ & $\begin{array}{l}\text { We shall evaluate the ability of employees to } \\
\text { make nontraditional nd nonstandard decisions, } \\
\text { determine the level of their ability to professional } \\
\text { upgrading }\end{array}$ \\
\hline
\end{tabular}




\begin{tabular}{|l|l|}
\hline $\begin{array}{l}\text { Evaluation of promptness and super- } \\
\text { standard activity of an employee }\end{array}$ & $\begin{array}{l}\text { We shall evaluate the ability of larger volume of } \\
\text { work fulfilment, than it has been set by the head } \\
\text { of the company }\end{array}$ \\
\hline $\begin{array}{l}\text { Evaluation of an employee's ability } \\
\text { to fulfill managerial activity }\end{array}$ & $\begin{array}{l}\text { We suppose to evaluate leadership qualities, } \\
\text { sociability, Предполагается оценка лидерских } \\
\text { качеств, коммуникабельности, propensity } \\
\text { towards conflict, culture level and role in a group }\end{array}$ \\
\hline \multicolumn{1}{|c|}{ Evaluation of personnel policy, professional skills and results of HR service activity } \\
planning of labor resources & $\begin{array}{l}\text { We shall evaluate the ability of personnel } \\
\text { attraction and training program, availability of } \\
\text { methodology for calculation of the necessary } \\
\text { employees number by categories, work with the } \\
\text { personnel reserve }\end{array}$ \\
\hline $\begin{array}{l}\text { Evaluation of availability and degree } \\
\text { of motivation and incentive system } \\
\text { development }\end{array}$ & $\begin{array}{l}\text { We shall analyze the structure of labor payment, } \\
\text { share of bonuses in labor payment; the } \\
\text { availability of schemes personifying payment } \\
\text { depending on the activity effectiveness, } \\
\text { compliance of developed principles, salary and } \\
\text { bonuses structure with the labor efficiency and } \\
\text { productivity, labor market conditions }\end{array}$ \\
\hline $\begin{array}{l}\text { Evaluation of personnel training } \\
\text { system }\end{array}$ & $\begin{array}{l}\text { We shall analyze and evaluate the retraining, } \\
\text { education, upgradingof employees system in } \\
\text { terms of expences, practical orientation and } \\
\text { training programs as well as the activity results } \\
\text { of employees upon training,change of social and } \\
\text { psychological climate and motivation towards } \\
\text { labor. }\end{array}$ \\
\hline
\end{tabular}

2. Understanding of the environment and internal control consisting in accounting policy and its changes consideration; determining the impact rendered by the new accounting and auditing standards; accumulation by the auditor of knowledge on accounting and internal control systems; establishing control tests and substantive procedures [20].

3. A description of the risk and materiality, in particular, the expected assessment of the control system risk and establishment of main directions of the audit; determination of the materiality level; the likelihood of material misstatement and fraud, including for past periods; identifying problem areas of accounting, including those associated with valuation knowledge; possible focus on specific areas of the audit; the impact of information technology on auditing; functioning of the internal audit service and its intended impact on the external audit.

4. Description of the nature, timing and scope of procedures.

On the basis of the general audit strategy, the head of the audit team draws up a personnel audit plan, which indicates the amount of upcoming work; the main activity lines of the enterprise; sections of the socio-economic and other reporting subject to verification and analysis; ways and methods of testing for each section; work fulfillment term; assignment of responsibilities to personnel auditors; forms of working papers and the procedure for their execution (Table 2) [4].

Table2.Personnel audit plan (fragment)

\begin{tabular}{|l|l|l|l|}
\hline No & $\begin{array}{l}\text { List of auditors services by } \\
\text { persinnel audit directions }\end{array}$ & $\begin{array}{l}\text { Methodological } \\
\text { instruments }\end{array}$ & $\begin{array}{l}\text { Working } \\
\text { documents of the } \\
\text { auditor }\end{array}$ \\
\hline
\end{tabular}




\section{Auditof personnel activity}

\begin{tabular}{|c|c|c|c|}
\hline \multicolumn{4}{|c|}{ 1. Auditof personnel activity } \\
\hline 1.1 . & $\begin{array}{l}\text { Audit of professional skills, } \\
\text { vocational and innovative } \\
\text { potential of an employee }\end{array}$ & $\begin{array}{l}\text { Matrix method, } \\
\text { Method of scoring } \\
\text { evaluation, } \\
\text { Method of production } \\
\text { characteristics system }\end{array}$ & $\begin{array}{l}\text { Combined } \\
\text { statement by the } \\
\text { results of the audit }\end{array}$ \\
\hline 1.2 . & $\begin{array}{l}\text { Audit of the employees ability } \\
\text { to independent work, } \\
\text { fulfillment of representative } \\
\text { functions, work in group and } \\
\text { management activity } \\
\text { fulfillment [21] }\end{array}$ & $\begin{array}{l}\text { Objectives fulfillment } \\
\text { evaluation, } \\
\text { Grouping system, } \\
\text { "360 degrees" method, } \\
\text { Group discussion }\end{array}$ & $\begin{array}{l}\text { Combined } \\
\text { statement by the } \\
\text { results of the audit }\end{array}$ \\
\hline \multicolumn{4}{|c|}{ 2.Personnel processes audit } \\
\hline 2.1 . & $\begin{array}{l}\text { Audit of processes of labor } \\
\text { resources planning, } \\
\text { recruitment and selection of } \\
\text { personnel }\end{array}$ & $\begin{array}{l}\text { Selection and analysis of } \\
\text { documents } \\
\text { analysis of objective } \\
\text { indicators by the quantity }\end{array}$ & $\begin{array}{l}\text { Analytical table of } \\
\text { indicators for labor } \\
\text { resources planning } \\
\text { evaluation, } \\
\text { recruitment and } \\
\text { selection of } \\
\text { personnel }\end{array}$ \\
\hline 2.2 . & $\begin{array}{l}\text { Audit of motivation system } \\
\text { and labor incentives }\end{array}$ & $\begin{array}{l}\text { Questionnaire/intrview of } \\
\text { the top managers and } \\
\text { separate HR specialists, } \\
\text { business processes } \\
\text { description, key employees } \\
\text { assessment }\end{array}$ & Audit questionnaire \\
\hline \multicolumn{4}{|c|}{ 3.Audit of the personnel potential } \\
\hline 3.1 . & $\begin{array}{l}\text { Audit of the staffing level on } \\
\text { the whole by the enterprize } \\
\text { and by the management levels, } \\
\text { turnover rate of personnel }\end{array}$ & $\begin{array}{l}\text { Analysis of objective } \\
\text { indicators by outman }\end{array}$ & $\begin{array}{l}\text { Analytical table of } \\
\text { indicators for } \\
\text { evaluation of } \\
\text { staffing level on the } \\
\text { whole by the } \\
\text { enterprize and by } \\
\text { the management } \\
\text { levels, turnover rate } \\
\text { of personnel }\end{array}$ \\
\hline 3.2 . & $\begin{array}{l}\text { Audit of compliance of the } \\
\text { personnel preparation to the } \\
\text { requirements of professional } \\
\text { and job competence }\end{array}$ & $\begin{array}{l}\text { Method of evaluation sum, } \\
\text { Supervision of the key } \\
\text { managerial comminications } \\
\text { process (meetings, } \\
\text { consultations, inspections), } \\
\text { Key employees assessment }\end{array}$ & $\begin{array}{ll}\text { Audit } & \text { results } \\
\text { statement } & \end{array}$ \\
\hline 3.3 . & $\begin{array}{l}\text { Audit of the personnell } \\
\text { structure by social and } \\
\text { demographic characteristics }\end{array}$ & $\begin{array}{l}\text { Analysis of objective } \\
\text { indicators by social and } \\
\text { demographic } \\
\text { characteristics }\end{array}$ & $\begin{array}{l}\text { Combined } \\
\text { statement by the } \\
\text { results of the audit }\end{array}$ \\
\hline
\end{tabular}

The audit plan reflects in detail all the procedures that are necessary for implementing a personnel audit strategy. The need for such a detailed elaboration of the plan is due to the fact that it is essentially an instruction manual for auditors. In addition, the plan is a basic document that allows the auditors to perform tasks, as it defines the number of auditors 
needed to conduct a personnel audit, the scope and content of the work. When developing a personnel audit plan and determining the methods of verification, it should be taken into account that audit procedures should contribute to identifying the presence of significant distortions and inconsistencies of social and economic indicators.

Separate sections and the entire audit plan can be coordinated and discussed with the management and representatives of the workforce in order to improve the efficiency of personnel audit and coordinate audit procedures with the work of the personnel of the audited entity [22]. Thus, by development of the personnel audit strategy, one should find out the opinion of the management of the economic entity on the factors essential for the implementation of an effective personnel policy; on possible problems and risks of concern to managers. At drawing up a personnel audit plan, the criteria chosen for evaluating the effectiveness of personnel policy shall be discussed and, if possible, agreed with the managers of the audited entity.

\section{Results}

At the second - functional - stage, the divisions provide information on the performance of management functions, the responsibility centers are determined, established key performance indicators, workload of employees by divisions, the received information and internal regulatory documentation is analyzed, databases and software studied, and the results of previous audits analyzed.

Upon examining all the documents, personnel auditors are engaged in collecting audit evidence, determining their sources and documenting the received information in accordance with the International Standard on Auditing 500 "Audit evidence".

The analysis and processing of information is one of the most labor-intensive work types in the process of the personnel audit. It is carried out to identify unusual, critical or incorrect situations in the personnel policy pursued by the object of personnel audit. In the course of the analysis, the obtained information is compared with the predicted results of the activity, with the average industrial indicators, with the standards, the best results, the indicators for the previous periods.

Personnel auditor identifies the relationship between:

- the information of a social nature and the corresponding financial information (the ratio of the number of laid-off workers and the cost of compensation for unused leave at dismissal); - the individual indicators, which must comply with the plans of the customer organization (staff turnover, wage rate).

According to the International Audit Standard 230 "Audit documentation", information obtained during a personnel audit shall be reflected in working papers. One of these working documents can be classified as a questionnaire (Table 3).

Table 3.Personnel audit plan (fragment)

\begin{tabular}{|l|l|}
\hline \multicolumn{1}{|c|}{ Question for the control } & $\begin{array}{l}\text { Auditor's } \\
\text { remark }\end{array}$ \\
\hline $\begin{array}{l}\text { 1. Does the social policy in respect of the staff in comply with the goals } \\
\text { and strategy of the enterprise development }\end{array}$ & \\
\hline 2. Does the planned staff number comply with the production program & \\
\hline $\begin{array}{l}\text { 3. Does the quantitative and qualitative staff content comply with the } \\
\text { strategic and tactic goals of the company }\end{array}$ & \\
\hline $\begin{array}{l}\text { 4. Is the personnel workload stabile including among the most } \\
\text { vulnerable social groups (women, disabled, pre-pension age persons) }\end{array}$ & \\
\hline $\begin{array}{l}\text { 5. Do the applied methods of personnel recruiting and selection comply } \\
\text { with the social and economic effectiveness and legislation }\end{array}$ & \\
\hline
\end{tabular}




\begin{tabular}{|l|l|}
\hline $\begin{array}{l}\text { 6. Do the applied personnel assessment system and merit rating comply } \\
\text { with the social and economic effectiveness and strategic goals of the } \\
\text { enterprise }\end{array}$ & \\
\hline $\begin{array}{l}\text { 7. Do the labor payment practice, personnel incentives, retraining and } \\
\text { upgrading forms comply with the strategic and current goals of the } \\
\text { enterprise and its staff interests }\end{array}$ & \\
\hline $\begin{array}{l}\text { 8. Has the system of personnel capacity been established at the } \\
\text { enterprise, and is it efficiently enough applied in the system of personnel } \\
\text { development }\end{array}$ & \\
\hline $\begin{array}{l}\text { 9. Is there any document formulating the main content and principles of } \\
\text { staff policy at the enterprise }\end{array}$ & \\
\hline $\begin{array}{l}\text { 10. Does the staff policy comply with the Russian and international } \\
\text { legislation }\end{array}$ & \\
\hline $\begin{array}{l}\text { 11. Is the staff policy a9imed at solving the strategic goals in the field of } \\
\text { human resources management }\end{array}$ & \\
\hline $\begin{array}{l}\text { 12. Is the staff strategy considered in the main documents of the } \\
\text { enterprise (Charter, Regulations on compensation, etc.) }\end{array}$ & \\
\hline 13. Is the staff policy directed at the solution of the staff issues & \\
\hline $\begin{array}{l}\text { 14. Are the managers of all levels included into the process of staff } \\
\text { policy realization }\end{array}$ & \\
\hline $\begin{array}{l}\text { 15. Does the professional competence of all key managers, human } \\
\text { resources management service structure, regulation on the staff service } \\
\text { comply with the enterprise strategy }\end{array}$ & \\
\hline \begin{tabular}{l} 
16. Is the social direction of staff policy provided for \\
\hline 17. Is the control of staff strategy realization provided for
\end{tabular} & \\
\hline $\begin{array}{l}\text { Auditor: } \\
\text { signature }\end{array}$ & \\
\hline
\end{tabular}

\section{Discussion}

In our opinion, special attention should be paid to the final stage of personnel audit. The final third stage stipulates: drawing up a report, which determines the responsibility of the personnel in the personnel audit company, analyzes the principles of personnel policy, and proposes incentive measures. The report shall reflect all stages of the personnel audit:

- the stage of preliminary work with documents - recording all sections and checked pages of documents; documenting the results of the control; recording deviations and including in the report; offering the activities for the development of personnel office work;

- the stage of collecting and processing analytical evidence - clear recording of deviations, citing the personnel audit protocol; assessing of deviations; activities for the work improvement are proposed.

While assessing deviations, one should take into account their type, significance, frequency of occurrence and influence on the personnel policy of the enterprise and ensuring socio-economic achievements. For the successful implementation of the personnel policy of the audited object, the report shall contain specific recommendations to solve a particular problem of assessing the individual characteristics of the employees in the organization. With the help of individual characteristics of personnel potential, one can assess the professional and personal qualities of individual workers, specialists, managers: their qualifications, psycho-physiological features, professional experience, and 
competitiveness, as well as compliance of the level of personnel training with the requirements for official and professional competence. Using these types of performance evaluation of personnel structures and specialists, it is possible get effective results of personnel audit.

The audit report is a final document formed by the results of the personnel audit. It indicates the object of the personnel audit and all aspects in relation to which the personnel audit has been carried out. The audit report shall take into account all the substantial circumstances affecting the accuracy of statements in accordance with the International Audit Standard 700 "Formation of opinion and drawing up an opinion on the financial statements".

The final personnel audit procedures are:

- analysis of all fulfilled procedures, made conclusions and decisions in order to establish the fact of fulfillment in respect of the personnel audit plan items and verify the accuracy of the made conclusions;

- compilation of the received information and formation of opinion on the results of the research;

- preparation of a written document, revealing the significant shortcomings identified in the process of an audit, the inconsistency in the system of socio-economic indicators and possible ways of their improvement.

\section{Conclusions}

Thus, the process of a personnel audit implies the formation of the reliable information. It is a basis for a clear picture of the personnel policy and the personnel management system, namely, the company's internal processes, employees' apprehension of colleagues' work, the problems, which occur in the process of the work fulfillment on the part of the personnel. Basing on these data, the auditor can determine the system of corrective measures and develop a strategy for enhancing the personnel potential of the organization.

The following processes occur as a result of a personnel audit: systematization and integration into the enterprise management system of a complex variety of work related to personnel management; reliable information development on the state of the personnel management system and personnel policy, on the arising problems related to the performance by the staff of their work duties.

Application of the methodological tools considered in the article in the process of conducting a personnel audit contributes to the development of reliable information giving a clear picture of the personnel policy and the personnel management system status, namely, the internal processes in the company, employees' apprehension of colleagues' work, the problems, which occur in the process of the work fulfillment on the part of the personnel. Basing on these data, the auditor can determine the system of corrective measures and develop a strategy for enhancing the personnel potential of the organization.

\section{References}

1. Dz. Faizrakhmanov, A. Zakirova, G. Klychova, A. Yusupova, A. Klychova, E3S Web of Conferences 91, 06004 (2019) doi.org/10.1051/e3sconf/20199106004

2. A.A. Ajupov, A.A. Kurilova, M.A. Azarskaya, L.Y. Yakovleva, T.U. Serebryakova, Research Journal of Applied Sciences, 11, 1166-1171 (2016) DOI: 10.3923 rjasci.2016.1166.1171 
3. G.S. Klychova, A.R. Zakirova, K.Z. Mukhamedzyanov, M.S. Faskhutdinova, Mediterranean Journal of Social Sciences, 5(20), 220-224 (2014) DOI:10.5901/mjss.2014.v5n24p104

4. A. Zakirova, G. Klychova, A. Yusupova, V. Kirillova, I. Gimadiev, E3S Web of Conferences 91, 06003 (2019) doi.org/10.1051/e3sconf/20199106003

5. Sh. Haneda, K. Ito, Research Policy, 47(1), 194-208 (2018) https://doi.org/10.1016/j.respol.2017.10.008

6. A.S. Mukhina, Asian Social Science, 11(8), 58-64 (2015) DOI: 10.5539 / ass.v11n8p58

7. G. Klychova, A. Zakirova, E. Sadrieva, F. Avkhadiev, A. Klychova, E3S Web of Conferences 91, 06002 (2019) doi.org/10.1051/e3sconf/20199106002

8. G.S. Klychova, A.R. Zakirova, E.R. Kamilova, International Business Management, 10, 5254-5260 (2016) DOI: 10.3923 / ibm.2016.5254.5260

9. J.A. Gonzalo-Angulo, A.M. Garvey, Revista de Contabilidad, 21(2), 107-115 (2018) doi.org/10.1016/j.rcsar.2018.05.004

10. G.S. Klychova, B.G. Ziganshin, A.R. Zakirova, G.R. Valieva, A.S. Klychova, Journal of Engineering and Applied Sciences, 12, 4958-4965 (2017) DOI: 10,3923 / jeasci.2017.4958.4965

11. H. Li-Jen, International Business Management, 9, 1686-1697 (2015) DOI: 10.5539 / ass.v1 $1 \mathrm{n} 8 \mathrm{p} 58$

12. S. Woo, H. Lim, Asian Social Scienc, (11-18), 144-152 (2015) DOI: 10.5539 / ass.v11n18p144

13. V. Nazarova. International Business Management, 9, 41-53 (2015) DOI: 10.3923 / ibm.2015.41.53

14. M.H. Christ, A. Masli, N.Y. Sharp, D.A. Wood, Accounting, Organizations and Society, 44, 37-59 (2015) doi.org/10.1016/j.aos.2015.05.004

15. J.G. Zwed, R. Adnan Al-Rubaye, Journal of Engineering and Applied Sciences, 14, 600-609 (2019) DOI: 10,3923 / jeasci.2019.600.609

16. A. Susanto, International Business Management, 10, 5523-5529 (2016) DOI: 10.3923 / IBM.2016.5523.5529

17. M. Deldoost, J.E. Wagner, International Business Management, 10, 1192-1202 (2016) DOI: $10.3923 / \mathrm{ibm} .2016 .1192 .1202$

18. M.N. Hisham Osman, S.Z. Turmin, H. Muhamad, R. Hussain, International Business Management, 10, 3733-3738 (2016) DOI: 10.3923/ibm.2016.3733.3738

19. T.V. Balabanova, M.V. Vladyka, O.V. Vaganova, S.N. Tsiguleva, S.A. Kucheryavenko, International Business Management, 9, 1629-1633 (2015) DOI: 10.3923 / ibm.2015.1629.1633

20. H. Li, J. Dai, T. Gershberg, M.A. Vasarhelyi, International Journal of Accounting Information Systems, 28, 59-76 (2018) doi.org/10.1016/j.accinf.2017.12.005

21. M. Mohammed, D. Mébarek, B.Wafa, Ch. Makhlouf, Safety and Health at Work, 7(4), 299-306 2016 doi.org/10.1016/j.shaw.2016.04.007

22. D.B. Bryan, Advances in Accounting, 36, 11-26, (2017) doi.org/10.1016/j.adiac.2016.09.005 